\title{
TRANSNATIONAL COMPANIES AND MULTICULTURALISM: CHALLENGES FOR ANALYSIS MODELS IN INTERNATIONAL MANAGEMENT
}

AS EMPRESAS TRANSNACIONAIS E MULTICULTURALISMO: DESAFIOS PARA OS MODELOS DE ANÁLISE EM GESTÃO INTERNACIONAL

\section{Ana Christina Celano Teixeira}

anacelano@gmail.com

EBAPE/FGV, Rio de Janeiro/RJ, BRASIL

\section{Daniella Munhoz da Costa Lima}

danimunhoz@yahoo.com.br

UNIGRANRIO, Rio de Janeiro/RJ, BRASIL

\section{Ana Lucia Malheiros Guedes \\ almguedes@gmail.com \\ UNIGRANRIO, Rio de Janeiro/RJ, BRASIL}

\section{Eliane Maciel}

maciel.eliane@gmail.com

UNIGRANRIO, Rio de Janeiro/RJ, BRASIL

\begin{abstract}
The purpose of this article is to discuss multiculturalism in transnational companies and their implications for analysis models in international management. A qualitative approach, through a case study was conducted in an American subsidiary of a Brazilian transnational company. The data were collected through interviews and respondents were also asked to do drawings or collages. The data were analyzed in an interpretive way. It was observed that, in the context of the analyzed subsidiary, the diversity of the workforce needs to be considered by management models. The article is concluded with reflections on the implications of multiculturalism on International Management models, including the need to consider the specific cultural contexts and their diversity in the construction of new analysis possibilities.
\end{abstract}

Keywords: International management. Multiculturalism. Transnational companies. Organizational culture.

\section{Resumo}

O propósito desse artigo é problematizar o multiculturalismo nas empresas transnacionais e suas implicações para os modelos de análise em Gestão Internacional. Foi realizado um estudo de caso de caráter qualitativo numa subsidiária americana de uma empresa transnacional brasileira. A coleta de dados foi realizada por meio de entrevistas e desenhos e colagens elaborados pelos respondentes e os dados foram analisados de forma interpretativa. Pode-se observar que no contexto da subsidiária analisada a diversidade da força de trabalho precisa ser considerada pelos modelos de gestão. O artigo é finalizado com reflexões sobre implicações do multiculturalismo para os modelos de Gestão Internacional, entre elas, a necessidade de considerar os contextos culturais específicos e sua diversidade na construção de novas possibilidades de análise.

Palavras-chave: Gestão internacional. Multiculturalismo. Empresas transnacionais. Cultura organizacional. 


\section{Introduction}

In 2008, faced with an amazing workforce composition, a survey was conducted regarding a Brazilian transnational company (TNC) focused on internal communication in its North American subsidiary. Among the nearly 500 employees working there, there were representatives from 28 different nationalities. This fact was added to other revelations and experiences from similar studies conducted for the Company in nine countries. This led to deeper studies of these results, as well as an analysis of the importance of diversity in the organizational context.

The literature suggests that in emerging transnational organizations, when local cultural traits are taken in consideration and integrate its cultural identity, organizational communication dysfunctions are minimized, fostering chances of attaining organizational goals. Thus, it is important to search for identity, via complexity, in what is diverse and fragmented, respecting local traits, preserving and building organizational identity in a joint, participative, and flexible way (NKOMO; COX, 2006).

As far as organizational communication is concerned, this goes beyond a traditional view supported by the 'conduit metaphor' and allow organizations to be seen as texts: that is, as ritualized patterns of interaction that transcend immediate conversations, and where, in organizational discourse, action and meaning intermingle (PUTNAM et al., 2004).

Furthermore, the internationalization process brings about examining varied forms of resistance, not only overt ones. These are frequently associated with a skeptical and critical perspective of globalization, but also can unveil subtler hidden manifestations; object of interest of Latin-American cultural studies (MOREIRAS, 1999). This double switching movement allows us to think 'cultures' - including organizational culture (MARTIN et al., 2006) - as processes that, almost at the same time, could split (Brazilian headquarters vs. American subsidiary as the traditional dilemma between headquarters and subsidiaries) and could try to unite everything and everybody in the organizational identity of an emerging transnational company.

This paper is structured as follows: the next section presents considerations on the limits and possibilities of analysis models currently adopted in international management field and cross cultural issues. After that, are presented some aspects of the complexity and fragmentation of american culture, reflections about the internationalization process of Brazilian companies and about the organizational culture and national culture. Then, some considerations about the methodological approach will be made, data and drawings will be discussed and, finally, the final considerations will be presented.

\section{New Scenarios and the need for new or renewed analysis models}

Much of the literature on international business consists of generalizations which do not properly consider contextualization and apply to more mainstream models in developed countries (RAMAMURTI; SINGH, 2009). Probably because of the historical development of internationalization of organizations, these standards tend to look proportionally much more at the relationships between North-North countries than between countries South-South or South-North. However, this scenario drastically changed with the acceleration of globalization and the consequent entry of new players in the world market, especially from southern countries such as Brazil. This recent change has created the need to seek new approaches that incorporate more significantly the contingent variables.

Tsui (2004) reinforces this picture and shows that it is increasingly important to extend the knowledge frontiers in management studies to include the diversity of international relations between countries. In short, we can no longer stick to the hegemonic models related to the developed countries, simply because, in practice these will prove inadequate.

The same author says that advances in the international management field and cross cultural issues has been slow and notes that the majority of academic world articles on this issue has been marked by U.S. hegemony, accompanied to a lesser extent by Western European countries. Thus, this particular hegemony, transported to the scene of thought and construction of organizational knowledge would take us almost unconsciously to a tendency to try manage under the influence of a sort of "eco-culture" that would interfere with the real "listening" to what each group has to say. Tsui (2004) further reinforces his reasoning that there needs to be an advance in global knowledge, in what the author calls context-specific or Indigenous research, which involves the highest possible level of contextualization, going beyond the existing theories. 
Within this proposed indigenous research, the priority should be to create knowledge that is valid, relevant, practical and meaningful to the organizations and their managers within the local context. In our experience, we would add that this proposal should occur in a permanent evolutionary approach that considers the absolute and continuous necessity of customization. This means being sensitive to local changes and their specific indicators, focusing on the psychological aspects that are affected by the social and cultural fabric and that can undergo radical changes under the influence of historical, political and the socioeconomic factors of the macro-environment.

Thus, the current scenario indicates the need to work on models that depend more on each country's context, as international relations are changing rapidly and that the late entrants (especially those from the southern countries, such as TNCs) will gain more prominence, expanding their roles in both the North and South. (CUERVO-CAZURRA, 2008).

Our experience in very specific and different organizational contexts leads us to believe today that understanding this organizational culture that builds and rebuilds the local daily life, finding their own solutions when faced with very specific contexts, implies and requires more than merely work out the difficulties and challenges in the foreign cultural context where the company is doing business.

It is essential to understand this unique operation in a highly contemporary complexity model. In the case of the Brazilian transnational company, it became clear that it was not enough to understand the North American culture, but to configure an originally Brazilian state company working on U.S. soil, with a high number of employees from various parts of the world (JACKSON et al., 1993).

According to Morin (2010), the world has become more complex since globalization. To this author, cultural globalization has three simultaneous aspects: (1) A homogenizing trend that contributes to the destruction of the original cultures or integrates and trivialize them; (2) A regeneration of some cultures which, because of its resistance to homogenization, will benefit from an exposure outside its borders; and (3) A penchant for cultural miscegenation, some extremely creative.

The issue is that today we are living a moment of transition, in which there doesn't appears to be one dominant model, but a simultaneous coexistence and instability of models, which further increases the whole complexity.

Barnejee and Linstead (2001) hypothesize that firms in the internationalization process, while working outside their countries, end up more easily incorporating in its work force, individuals previously excluded or marginalized. Among these more easily included workers, are the women and immigrants from minority groups (CALAS; SMIRCICH, 1993). All these authors indicate that the success of diversity management is the key to the contemporary organizational challenge. Thus, a new globalization argument appears bringing the multiculturalism question as a concept that can be used to solve the ever sensitive and complex issues of cultural diversity. This is a concept that no longer considers globalization only for its economic standpoint, but as an irreversible social, cultural, political and historical progression.

Next, we look at some of these points.

\section{Fragmentation and complexity of the American Dream}

From the beginning, understand and contextualize a little more this environment in its widest sense i.e. the United States of America - seemed the best way for a deeper discussion about the presence of a Brazilian transnational in its territory.

Who are the Americans? What do they want, think, feel and dream for the future? Can you define a profile of the inhabitants of the current dominant power on a planetary level? Since the early twentieth century, several studies have addressed these and other relevant issues. "America" as we call it - a symptomatic reference to the continent and not to one of its countries - has stirred up emotions and world views, as an omnipresent phantom with which we are forced to interact, to adhere to or deny their omens (SWEIG, 2006; BARBEIRO, 2007).

From Sartre to John Lennon, Einstein to the Dalai Lama, from Right to Left, no one balked at offering his opinion - not rarely, very negatively - about a country that not only forged a very special dynamism to guide their interrelationships, but also sold this same model to the vast majority of western nations that currently practice regional versions of the "American way of life", with greater or lesser success. More than in the economy, in foreign policy and military might, the USA exercises hegemony in the minds of nations and individuals: This is no small thing (BANDEIRA, 1997). 
The USA is not depicted, as only one country. In its genesis is a desire, often illusory, of prosperity, unlimited opportunity and personal freedom. They forged a democracy model that is being exhaustively persecuted, imitated and criticized, since 1776: the U.S. independence was, in fact, the first sign of the wave of proclamations of independence and the proliferation of republics that would sweep the continent in the $19^{\text {th }}$ century. However, for more than 100 years everybody knows that "the North Americas" became many. Its 300 million people spread over 50 states hold today very little of the Europeanized physiognomy, liberal, progressive and mercantilist that we've come to identify with the original 13 colonies. In this first decade of the new millennium, we face a country where no less than $35 \%$ of the population is comprised of individuals from other places. A poignant example is that which shows the position of the population of Latin American origin (HARLING; HAMID, 2006).

According to the latest Census, the 2006, about 40.5 million, or $14.2 \%$ of the total population consisted of Hispanics, many of them white: in 1970, when they began the statistics, Hispanics were less than nine million - and the government estimated that, given the proportionately higher birth rate among this population group and the continuing arrival of immigrants, Latinos will be just over 102 million in 2050 .

Thus, we must ask: What will be the face of America in the next century? The more we approach this great enigma, the more we see the austere figure and supposedly French or classical Statue of Liberty fragment into millions of other figures representing a variety as vast and complex as our own national image (CAMPBELL; MOYERS, 1988).

In addition to the basic issues of language, nationality and religion, we also know that Americans rarely share any cultural or ideological logic, beyond their frontiers. The artistic and cultural events, food, clothing and everything else that characterizes a model of living varies as much as from New York, Nashville and St. Louis as between London, Guyana and Singapore. This social expression is so multifaceted that Campbell and Moyers (1988) could not avoid the statement: "The United States has no ethos." Thus, for this important twentieth century mythologist, the USA would be the only nation in the world that would entirely lack in its own entire way to do and think about things, something that indeed would define it as having "one dominant thought or way to be typically American". In his long interview with Bill Moyers, which led to the seminal book "The Power of Myth" (1988), Joseph Campbell said that the North American ethos had gone along with the buffalo and the Plains Indians, and there was nothing to replace it, neither by building positive models for a new society, nor support the imagination of the newest generations.

This was the representation of the diversity scenario we found in this TNC in the USA, with its picture of extreme workforce diversity, with employees from 28 nationalities, from Venezuela, England, Portugal, India, China and Azerbaijan among others.

\section{The internationalization process of Brazilian Companies}

The internationalization of Brazilian companies from is a recent phenomenon in the global scenario (RAMAMURTI; SINGH, 2009). According to Fleury (2011), the literature in this regard is still ambiguous and even skeptical of their impact on the world economy. The theoretical basis for current studies are still those produced by the developed countries, and specific literature on this area of knowledge is still under construction (RAMAMURTI; SING, 2009). It is within this new context that there is the possibility to study their interactions and dynamics, as well as the impacts of the adoption of the Anglo-American literature uncritically (ALCADIPANI, 2010; FARIA; IBARRA-COLADO; GUEDES, 2010). Thus, the relationship between these Brazilian companies and their new audiences, requires new understanding of the internationalization logic.

The Brazilian transnational energy company studied in this paper, is now present in seventeen countries worldwide and in almost all South America, working in distribution, exploitation and refining of fuels and in the gas sector. The company is presented in United States since 1987, but has developed international activities in other countries since the 1970s. However it is important to notice that was after 1996 (when it began operating in Bolivia) and after 2002 (when it acquired a major Argentine energy company) that it took a significant leap in its interests and effective participation as a company in a clear process of internationalization.

In this context, the relationships between local employees and the corporate's organizational structure of a foreign company have often hide dimensions that are not easily revealed, but should be widely considered in International Management (IM) studies. 
It is still necessary to critically consider the definitions adopted within the IM field, to contextualize the international performance of the companies. Especially when we are referring to the concepts of transnational and multinational company.

This distinction does not seem clear as some authors wish. However, for differentiation purposes, to be characterized as multinational, a company must have operational bases in many countries as the very prefix 'multi' indicates. A transnational company does not necessarily mean that it should have operational bases in many other nations, but just some branches. Authors like Ianni (1998) express the idea that transnational organizations are gradually freed from some injunctions or limitations inherent in nation states. This perspective fits into the context of the broadly internationalization of capital, through geographic dispersion of production caused by the new international division of labor. There is another metaphor for the designation of the company that goes beyond the nation state border limits, and that has been referred to as "global company". It is seen as an entity that transcends national boundaries where the national identity of the corporation must be replaced, under this view, for a strategic paradigm that knows no borders (FLEURY, 2011).

From another perspective, critics of globalization or capital globalization, consider the idea of capital without a country as mere rhetoric. In reality, these capital continue to maintain its administrative base in the hegemonic states where the vast majority of its shareholders live. Amin (2001) states that only their operations are transnational, but the property and its control are in their original countries and the profits are reverted to their respective headquarters located in developed countries.

\section{Organizational culture and national culture}

National culture can help explain differences in workrelated attitudes and values. The impact of national cultures in organizations has been explored in countless studies by various authors who developed diverse conceptual approaches and classification schemes (ADLER, 2002; HALL, 1977; HOFSTEDE, 1991; TROMPENNARS, 1994). Geert Hofstede was a pioneer author in the analysis of national cultures' influence on the culture of organizations and is one of the most quoted authors on the subject, in national and international academic production alike. For this reason, some of the main points of this author's studies are presented below.

Hofstede (1991) was interested in the interaction between national and organizational values, and conducted an intercultural research amongst the employees of a multinational company in over 40 countries, between 1967 and 1973, with the objective of identifying differences in national values systems through, initially, four dimensions: (1) power distance; (2) uncertainty avoidance; (3) individualism vs. collectivism; and (4) masculinity vs. femininity (HOFSTEDE, 2001; 1991). Later on, Hofstede's studies incorporated a fifth dimension: long-term orientation vs. short-term orientation.

Within the theory presented by Hofstede (2001; 1991), the individualism vs. collectivism dimension characterizes the nature of the individuals and the links established between them in a society. Individualism is an orientation towards oneself, whereas collectivism is chiefly oriented towards common goals and targets. The term "collectivism", in this sense, does not refer to political meanings, as in a State, but to a group. In individualist societies, people would be more inclined to worry solely about themselves and whomever they were directly connected to. (HOFSTEDE; McCRAE, 2004; HOFSTEDE, 2001; 1991)

Power distance measures the degree of how less powerful members of organizations accept an uneven distribution of power. (HOFSTEDE; McCRAE, 2004; HOFSTEDE, 2001; 1991)

Avoiding uncertainty addresses the ways by which an uncertain situation is avoided, putting in practice more formalized rules, giving up alternative ideas and behaviors, accepting the feasibility of absolute truths. National societies, in different degrees, use technology, legislation and religion to attain these goals. (HOFSTEDE; McCRAE, 2004; HOFSTEDE, 2001; 1991)

The masculinity vs. femininity dimension concerns the distribution of emotional roles between genders. While masculinity is related to competition and assertiveness, femininity is related to a more considerate behaviour with respect to others. (HOFSTEDE; McCRAE, 2004; HOFSTEDE, 2001; 1991)

Finally, long-term orientation shows how much a society adopts a pragmatic long-term perspective, looking ahead to the future; short-term orientation, however, indicates attachment to the past and history.

Comparing Brazilian and American scores under 
these national cultural dimensions, it is found: (1) US display scores that indicate a lower power distance than occurs in Brazil; (2) US is the most individualist country, while Brazil is more collectivist in $26^{\text {th }}$ position

Laurent (1983) addressed the issue of power distance. His research has been updated by Tanure (2005) and came to the result that in Brazilian culture the concentration of power leaves no doubt about who is responsible for the decision and not on who should implement what was decided.

Comparing the indices of individualism and collectivism it is necessary to distinguish a characteristic of the concept of "individual" and "person" in Brazilian society. According to DaMatta (1984), the "individual" is a seen as being someone anonymous. He is not identified as someone who is part of a certain circle of acquaintances, therefore worthy of trust or attention, being treated absolutely "within the expectations of the law."

It should be pointed out, however, that although these analyses are the basis for a large part of the study on internationalization and are still highly relevant, they may no longer be sufficient, in that are being reviewed and updated by Hofstede (1999) and expanded and criticized by other authors, such as Tsui (2004) and Jack et al., (2008), who consider many of its aspects are not yet contextualized and still full of excessive generalizations.

A criticized point in Hofstede's work is his vision of organizational culture as being uniform. In this sense, McSweeney (2002), who's considered one of the main attackers of Hofstede's work (1991), organized his arguments towards the criticism of assumptions he considered basic for the former's theory to make sense. The first of such assumptions would be indeed to assume a collective mind programming, which would result in the premise of the uniformity of organizational culture and in considering the small group who answered the survey could represent the national whole.

Hence, despite Hofstede's pioneering, it is a study done from the perspective of a "foreigner" in a multinational company, which imposes his world view and the dimensions considered important by him as forms of analysis and explanation matrix. Besides, the non-critical adoption of Hofstede's classification is susceptible to criticism from the post-colonialist perspective. Because, due to analyzing various countries in regard to the dimensions identified by him, according to his world views, and classifying them inside each dimension, the author is holding value judgment of the different cultures in question. Therefore, the post-colonialist perspective that questions the homogenization of elements transposed from the reality of a specific country, which explains reality according to its own vision and imposes it upon other cultures and realities, does not agree with this approach (PRASAD; PRASAD, 2001).

On the other hand, the high cultural complexity model currently faced by transnational corporations may no longer be sufficient, or even misleading, considering only these factors. It would be like creating a study that compares only two countries, Brazil and the USA, both holders of a cultural homogeneity that is only hypothetical.

In the studied case, this type of analysis would be based on the assumption - as explained, not applicable - that all the employees belong to the two compared nationalities. Moreover, even these nationalities were being considered in rather tight categories, without due consideration to the typical traits and varieties found in the very composition of these nationalities. In the Brazilian TNC in the USA case, it was observed that within the context of a predominantly American culture, the diversity of the workforce should be considered in the management model. This is because the fact should not be overlooked that a work force so multifaceted displays its own traits that can not and should not only be analyzed within a comparative perspective and little contextualized or within a culture-free theory (Jack et al. 2008; Tsui 2004).

Also in this line, according to Adler and Graham (1989), researchers should not become imbued with the certainty that they know how to observe profound cultural, political, historical and economic differences. Adler and Graham (1989) feared that the observations and interpretations are not trustworthy, for they are themselves flawed by an approach modeled by a hegemonic vision.

\section{Methodology Approach}

The data used in this paper were obtained through an internal communication diagnosis conducted by the authors in the company's international unit in 2008. Thirty employees were interviewed and, as much diversity had already been identified in the company, with employees of twenty-eight different nationalities, a choice was made in which $50 \%$ of interviewees were North American and 50\% were from other 
nationalities. This choice allows for a comparison between the perceptions of American employees and those of other nationalities.

Regarding the interviewees' gender, the demographic profile of the company, which has a mostly male composition, was respected and, therefore, $80 \%$ of the interviewees were men and $20 \%$ were women. Regarding the educational level, $60 \%$ of the heard employees had a superior education and $40 \%$ had a secondary education.

Coherently with the theoretical perspective adopted in this paper, which points towards the implications of diversity and multiculturalism in international management, a data gathering and analysis approach was chosen which allowed for an exploration of subjectivities and riches of the related cultural aspects. Therefore, an approach was used which, besides the interviews, included the production of drawings and collages by the interviewees.

Apart from individual interviews and filling out a questionnaire, respondents were asked to do some drawings or collages which sought to answer, among others, the following question: "What does it mean to you to be part of that company?"

To ensure impartial analysis and avoid possible interference issues observed during the on-site survey, a methodology was established by which the drawings collected during the interviews were sent for analysis before any prior information was available, except the name of the work unit, gender and age of the respondent. Secrecy and confidentiality were maintained and all information that would permit identification of the authors of the drawings had been omitted.

The relevance of using images in studies dealing with cultural aspects has been noticed by countless authors (PINK, 2007; MACDOUGALL, 1997; STOLLER, 1997). According to Pink (2007, p. 21) "they [images] are inextricably interwoven our personal identities, narratives, lifestyles, cultures and societies, as well as with definitions of history, space and truth."

The adoption of a visual approach, denominated by Pink Visual Ethnography, has been defended by the author as the key to a methodological line which considers the visual dimension as an alternative to the methodologies traditionally utilized in social science, especially in studies about cultural aspects. Pink (2007, p.6) also argues that "there is no essencial hierarchy of knowledge or media for ethnographic representation". Thus, in some researches the visual may become more important than the spoken or written word, in others it will not.

MacDougall (1997) also rejects the idea that the written word is essentially a superior medium of ethnographic representation. Therefore, images should be regarded as an equally meaningful element in cultural studies.

Similarly, Stoller (1997) suggests a multisensory approach to cultural studies, as it would be relevant and analytically important to consider how perception in some kinds of societies devolves not simply from vision, but also from smell, touch, taste and hearing.

Thus, the analysis perspective adopted in this article agree with Pink (2007, p.6): "Images may not necessarily be the main research method or topic, but through their relation to other sensory, material and discursive elements of the research images and visual knowledge, will become of interest".

Regarding the analysis of the data collected in the American subsidiary for this study, the drawings and montages made by the interviewees were analyzed in their subjective aspects by a qualitative and interpretative analysis, considered by a great number of researchers who use graphical projective techniques as a more revealing evaluation than a quantitative analysis. (ARZENO, 1995; GRASSANO, 1996).

The interpretative approach is adequate to the object of this paper, as the study of human culture and behavior in the work frame in transnational organizational environments is marked by complex networks of connected meanings which combine rational and nonrational, real and self-constructed, elements (FLEIG et al, 2005).

Still concerning the data analysis, the drawings were evaluated according to a previously established script, based on the studies of Van Kolck (1984) and Hammer (1981). It was also considered that the attributes of a drawing are influenced not only by psychological factors, but also by social and cultural variables (PICCOLO, 2005; VAN KOLCK, 1984).

\section{Drawing diversity / Findings}

To illustrate how diversity is significant in the context of an American subsidiary of a Brazilian transnational company, two collages/drawings are highlighted and compared in this paper. Both were produced, by two different employees: the first of American origin and the second Indian, during the individual interviews. 
As can be seen, a possible caption for the drawing showed in Figure 1 would be: "A demonstration of how North American culture is absorbing, assimilating and interpreting the company, based on the traditional values of their society. For the employee who built this collage, part that company seems to be something that boils down to one word: power. And he expresses this power openly, in several instances: from the stability that permits him to have a family (which inspired the picture of the women and child) to the example of physical strength, expressed in the figure of the physiculturist that is, also the goal to be reached by the rocket.

The rocket itself - for excellence, a phallic symbol could be related to the power of high technology, the domination of more distant and challenging frontiers, a target only the strong can achieve: appropriately, it is a symbol very much in the culture of that unit's employees, living in Houston with NASA as a neighbor. Thus, it can be deduced, a simple association, for this employee that the company is a family that empowers the author of the collage to project him upwards on the rocket's route, so he can achieve ever greater heights.

This family is sustained, probably in the strong arms of the smiling bodybuilder, sporting his impressive muscles for the anonymous woman whose image was cropped.

However, if we examine the underlying aspects of this bold design and which seems to have been designed to exalt a certain sense of superiority of the author, we find another element: an implicit aggressiveness. The smiling bodybuilder, with his leather outfit, is not just making a show of his own physical strength, also warns "do not come, who doesn't have: if you do anything I don't like, you'll see!" The implicit threat is associated with the author's commitment to the preservation of his dreams of a family and reaching new heights in his career (the rocket route), but also seem to indicate that if necessary he would be willing to defend these values even if it needed, "using his arms," i.e. making use of some type of violence, although not quite reaching the physical, may suggest a voracious competitiveness.

It is a possibility, as the drawing's author, in assimilating his self-personification, all the values typical of the traditional North American society, made him conscious that he was sending a message to Brazilian TNC on what it means to him to be part of the company - and in this instance, he has not failed to portray himself objectively, as an icon that would gather together all the elements of personal power. That is: a blatant demonstration of strength and superiority, crowned by goals emanating from a deeply individualistic viewpoint.

Figure 1: - Drawing made by employee of American origin

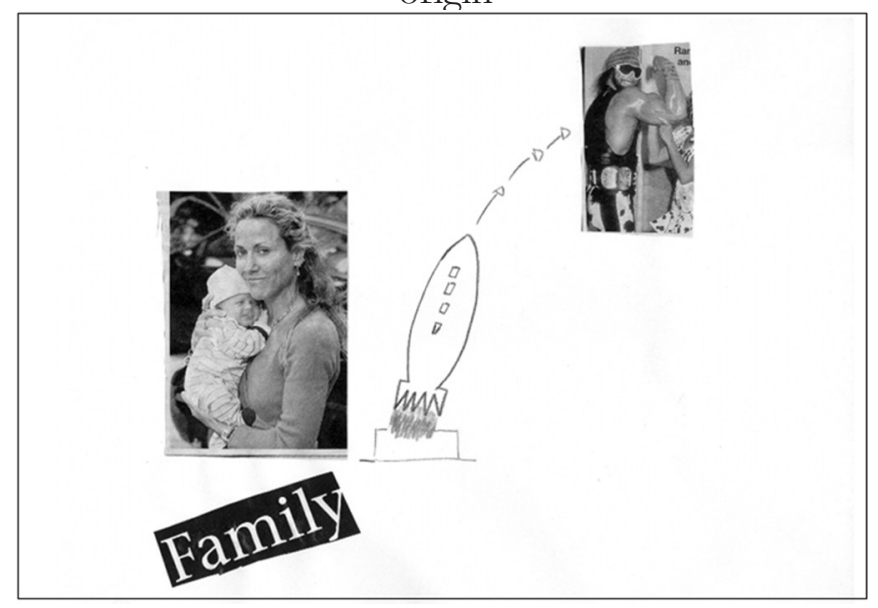

In striking contrast with this perception of himself and his role in the company's workforce, the author of the drawing in Figure 2, a member of the workforce of Indian origin, built a minimalist image of mathematical precision and blatantly collectivist. The author portrays himself as one of the cubes, or squares, which form a larger cube - possibly his own team or company. The symmetry of the design suggests a harmonious set of fittings and a positive sense of interdependence.

There is, however, without some "culture shock" that the Hindu employee portrays himself, in the general context as an integrant. Which suggests this conflict is the form chosen by the employee to portray him and his work environment: in general, squares or cubes are associated with very crystallized or imprisoning structures. There is a harmony in the employee who "paints" (marks) one of the squares to identify itself in the structure - but one can not ignore the psychological relationship of this type of design is always a reference to feelings of imprisonment, to be held in closed blocks, extreme closure. Thus, even under a guise of a "good fit", this drawing is a strong indication of rigidity. Another aspect that reinforces this potential need to "ventilate the structure" so subtle that it is almost invisible - the box is not closed on the right (traced in pencil). This refers to a "breather" as if the author wanted to inform you that in this so perfect and fair fit, the human has to "breathe," "express himself", "escape" to somewhere. 
Figure 2 - Drawing made by employee of Indian origin

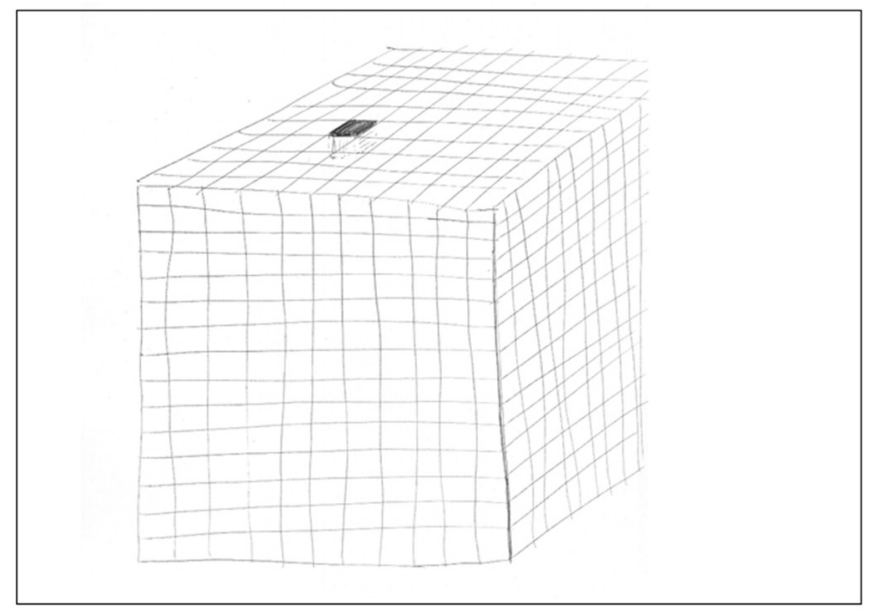

Thus, analysis of drawings and montages such as the ones done in Figures 1 and 2 were made in many contexts in the nine international units surveyed and not just in the USA. These analysis helped to confirm and consider important aspects usually not verbalized in the interviews, such as their efforts and commitment, as well as uncertainty, conflicts, conscious or underlying tensions and dichotomies between what is verbalized and what is shown in the working groups.

In addition to the aspects already exposed, it caught our attention, in the Brazilian TNC in USA unit, a possible aspect relevant to internal communications that pointed to an indication of the need to work long-term cultural change, with a focus on valuing the company itself, the Brazilian leadership and the respect for diversity: a significant number of the sampled drawings complained of a rivalry or imbalance of forces between the Brazilian company and its North American unit, or between Brazilian managers and their USA unit subordinates. These associations linked to the notion of superiority are tied together, in the sample, the suggestive icons of money and physical strength, merit being investigated. What leads to such speculation is the defiant attitude revealed in these drawings, as if the underlying words wanted to say that for all its financial power and that the Brazilian company is the business owner, American employees are very conscious that they are the "real power", dominant and hegemonic, and thus not willing to accept very well the apparent "reversal of relations" in which its workforce and "professional name" were "purchased" by a South American company.
In our final evaluation, we suggest that measuring this issue could avoid conflicts between leaders and the led, in the short and medium term; it could be an important preventive measure.

\section{Final Considerations}

In today's world, where distances have decreased rapidly and relationships have become more complex, the multiculturalism of the workforce, employed in transnational corporations, should be treated as a constant and strategic variable of the organizational management.

Based on this experience on American soil, it is considered very likely that the hypothesis raised by Barnejee and Linstead (2001) also applies to this company, i.e. as this is considers the case of a Southern company operating on North American soil, there is a certain "intrinsic flexibility," or "a priori", that facilitates the assimilation of a greater diversity in its workforce. Thus, Brazilian firms in the internationalization process would be in line with the perception that the TNC from the South, to settle in the North, from the outset show that, in addition to incorporating in the overseas operations the multiculturalism issue, it can act as a conductor and a facilitator of this phenomenon. Undoubtedly, the formation of an extremely multicultural workforce in the Brazilian company in the USA unit (28 nationalities/ethnicities, and the Brazilians and the Americans themselves), allows such a consideration.

But in the specific case, there are other aspects to consider before making this generalization, for example, the multiculturalism which has traditionally been a characteristic of this company, in Brazil largely by being a state enterprise where a majority of the workforce is recruited through a public selection process. This factor certainly may have contributed to the assimilation of diversity as being naturally "exported" in its internationalization, as part of the very unique culture of the company.

On the other hand, with the USA it can not be overlooked that the social pressure exerted by the extreme diversity that exists in the North American society itself, tends to carry and translate in an increasingly more visible way, also in the staff of the original local companies. So when the internationalization scenario is in the form of a highly complex society (which includes, in fact, most countries, for one reason or another, in the context 
of the globalized world), it is up to the researcher to always remember that each and any hypotheses must be evaluated case by case. Or at least be waiting for a confirmation, which can only be based on careful local analysis that focuses, over time, on the very process of the internationalization of Southern Companies with the subsequent entry in the North. This is an important field of study, since this process, still in its infancy, is tending to accelerate and intensify on a large scale, especially in view of the expected changes in the global economy in the coming years, with the rise of the so-called BRICs (Brazil, Russia, India and China) to roles of world players.

When we insist that these hypotheses indicate the possibility of future comparative research in the area, not only with Southern TNCs operating in North America, but also the Northern companies working in the South, we do so because we believe these future studies may shed light on the matter and bring out a more accurate perception about the veracity of these phenomena. In this way we can confirm if we are facing an isolated case or if its repetition emerges with similar or different intensity in other companies.

That is to say: confirming the warnings of Jack et al (2008) and Tsui (2004), we can not assume that studies and business models designed by and for certain companies, in certain societies and in certain moments of time, may simply be "transplanted" to other circumstances, without at least one adaptation or prior assessment of their validity. The organizational knowledge needs to be built and, therefore, the history, culture, worldview and the trajectory of each group involved are aspects that need to be considered. As in "all that is solid melts into air", often demonstrates that nothing is as it seems, when we put the object under closer and deeper observation, the strategic management and relationships established by the companies, inside and outside their "internal circuits", undergo a variation not only bigger but a wider range of chemical reactions that can be checked when similar compounds, but not identical, are subject to various conditions.

Another point of analysis that deserves a check is whether the management and organizational practices in these companies are taking into consideration that multiculturalism in their day-to-day activities. Again, we agree with Jack et al, (2008) and Tsui (2004), when both emphasize that understanding these differences and consideration of the issue of latent multiculturalism in people management is an important factor for the success of any transnational company. The analysis of the drawings of the studied company clearly shows the issue of diversity by comparing the traits of individualism and personal expectations in the collage produced by the North American employee and the traits of collectivism in the design of the Indian employee. The drawings also showed differences in employees' values that reflect elements of their cultures of origin, like aspects related to strength and power in the North American employee's drawing and aspects of harmony and interdependence in the Indian employee's drawing.

The complexity of the situation shows that the cultural dimensions become increasingly complex and difficult to be analyzed, understood and managed in a globalized context, since the organization's internal cultural fabric deals with individuals from multiple multicultural roots, a fact that is extremely important for business and management, as it directly impacts on the results obtained by the company.

Another point to be emphasized is the importance of using, in international management studies involving multicultural and diversity aspects, deeper methodologies, like drawings, collages and projective techniques that allow for the identification of contradictions and more subjective aspects that might not be identified by the sole use of traditional data collection and analysis methodologies.

We live in a time of transition in which a series of models are modified and mixed intensively, and therefore by their very nature, volatile and mutant, the analysis in this sector should be exhaustively intensified. In this way, we believe that effective management of diversity is one of the great challenges of international business and management.

\section{References}

\section{ADLER, N. J. International dimensions of organizational behavior. Cincinnati: South- Western, 2002.}

ADLER, N. J.; GRAHAM, J. L. Cross-cultural interaction: The international comparison fallacy? Journal of International Business Studies, v. 20, n.3, p. 515-537, 1989.

ALCADIPANI, R. Critical international management and international critical management: perspectives from Latin America. Critical Perspectives on International Business. v.6, n. 2/3, 2010. 
AMIM, S. Capitalismo, Imperialismo e mundialização. In: SEOANE, J; TADDEI, E. (Org.). Resistências mundiais: de Seattle a Porto Alegre. Petrópolis: Vozes, 2001.

ARZENO, M. E. G. Psicodiagnóstico clínico. Porto Alegre: Artes Médicas, 1995.

BANDEIRA, M. Relações Brasil-EUA no Contexto da Globalização. São Paulo: SENAC, 1997.

BANERJEE, S. B.; LINSTEAD, S. Globalization, multiculturalism and other fictions: colonialism for the new millennium? Organization, v. 8, n. 4, p. 683-722, 2001.

BARBEIRO, H. O Relatório da CIA: Como será o mundo em 2020. São Paulo: Ediouro, 2007.

CALÁS, M. B.; SMIRCICH, L. Dangerous liaisons: the feminine-in-management meets globalization.

Business Horizon, v. 36, n. 2, p. 164-80, 1993.

CAMPBELL, J.; MOYERS, B. The Power of Myth, New York: Dobleday, 1988.

CUERVO-CAZURRA, A. The multinationalization of developing country MNEs: the case of multilatinas. Journal of Internacional Management, v.14, n. 2 , p. 138-154, 2008.

DAMATTA, R. O que faz do Brasil, Brasil? Rio de Janeiro: Rocco, 1984.

FARIA, A.; IBARRA-COLADO, E.; GUEDES, A. Internationalization of management, neoliberalism and the Latin America challenge. Critical

Perspectives on International Business, v.6, n. 2/3, 2010.

FLEIG, D. G. et al. Reestruturação produtiva e subjetividade: análise interpretativa do significado do desemprego. Organização \& Sociedade, Salvador, v. 12, n. 33, p. 71-91, 2005.

FLEURY M. T. L. Brazilian Multinationals: Competences for Internationalization. Cambridge: Cambridge University Press, 2011. v. 1. 420p.

GRASSANO, E. Indicadores psicopatológicos nas técnicas projetivas. São Paulo: Casa do Psicólogo, 1996.

HALL, E. T. A dimensão oculta. Rio de Janeiro: Francisco Alves, 1977.

HAMMER, E. F. A técnica projetiva da casa-árvorepessoa: interpretação de conteúdo. In HAMMER, E. F (Org.). Aplicações clínicas dos desenhos projetivos. Rio de Janeiro: Interamericana, 1981.

HARLING, P.; HAMID. Y. Dossiê Guerra Infinita/ Mitos: A demonização forçada dos xiitas. Le Monde Diplomatique, Setembro de 2006.

HOFSTEDE, G. Cultures and organizations: software of the mind. New York: McGraw-Hill, 1991.

HOFSTEDE, G. The Universal and the Specific in 21st-Century Global Management. Organizational Dynamics, v. 28, n. 1, p. 34-43, 1999.

HOFSTEDE, G. Cultures consequences: Comparing values, behaviors, institutions and organizations across nations. Thousand Oaks, CA: Sage, 2001.

HOFSTEDE, G.; McCRAE, R.R. Personality and culture revisited: linking traits and dimensions of culture. Cross-cultural Research, v.30, n.1, p.52-88, 2004.

IANNI, O. Teorias da Globalização. Rio de Janeiro: Civilização Brasileira, 1998.

LAURENT, A. The culture of diversity of western conceptions of management. Human Resource management, v. 25, n.1, p. 91-102, 1983.

JACK, G. A.; CALÁS, M. B.; NKOMO, S. M.; PELTONEM, T. Critique and International Management: An uneasy relationship? Academy of Management Review, v. 33, n. 4, p. 870-884, 2008.

JACKSON, W. E.; STONE, V.; ALVAREZ, E. B. Socialization amidst Diversity: the Impact of Demographics on Work Team Oldtimers and Newcomers. In: CUMMINGS, L. L.; STAW, B. (Org.). Research in Organizational Behavior. Greenwich, CT: JAI, 1993.

MACDOUGALL, G. The visual in anthropology. In: BANKS, M.; MORPHY, H. (eds.) Rethinking Visual anthropology. Londres: Yale University Press, 1997.

MARTIN, J.; FROST, P. J.; O’NEILL, O. A. Organizational Culture: Beyond Struggles for Intellectual Dominance. In: S. R. Clegg, C. Hardy, T. B. Lawrence, and W. R. Nord (Eds.). The SAGE Handbook of Organization Studies. London: Sage, p. 725-753, 2006.

MC SWEENEY, I. Hofstede's model of national culture differences. Human Relations, v. 55, n.1, p.88-117, 2002. 
MOREIRAS, A. The Order of Order: On the

Reluctant Culturalism of Anti-Subalternist Critiques. Journal of Latin American Cultural Studies, v. 8, n. 1, p. 125-145, 1999.

MORIN, E. Meu Caminho. Rio de Janeiro: Bertrand Brasil, 2010.

NKOMO, S. M.; COX, T. Diversidade e Identidade nas Organizações. In: CLEGG, S. R; HARDY, C.; NORD, W. R. (Eds.) Handbook de Estudos Organizacionais: Modelos de Análise e Novas Questões em Estudos Organizacionais, v.1. São Paulo: Atlas, p. 332-358, 2006

PICCOLO, E. G. Os testes gráficos. In: OCAMPO, M. L. S. et al (col). O processo de psicodiagnóstico e as técnicas projetivas. São Paulo: Martins Fontes, 2005.

PINK, S. Doing Visual Ethnography. Londres: SAGE Publications, 2007.

PRASAD, A.; PRASAD, P. Otherness at large: identity and difference inthe new globalized organizational landscape. In: MILLS, A.; MARJOSA, I. Gender, identity and culture of organizations. London: Rotledge, 2001.

PUTNAM, L. L.; PHILLIPS, N.; CHAPMAN, P. Metáforas da Comunicação e da Organização. In: CLEGG, S. R; HARDY, C.; NORD, W. R. (Eds.) Handbook de Estudos Organizacionais: Modelos de Análise e Novas Questões em Estudos Organizacionais, v.3. São Paulo: Atlas, p. 77-125, 2004.

RAMAMURTI, R.; SINGH, J. Emerging Multinationals in Emerging Markets. Cabridge University Press, 2009.

STOLLER, P. Sensuous Scholarship. Philadelphia: University of Pennsylvania Press, 1997.

SWEIG, J. Friendly Fire: Losing Friends and Making Enemies in the Anti-American Century. Council on Foreign Relations. 2006

TANURE, B. Gestão à Brasileira: uma comparação entre América Latina, Estados Unidos, Europa e Ásia. São Paulo: Atlas, 2005.

TROMPENAARS, FONS. Nas Ondas da Cultura. São Paulo: Educator, 1994.

TSUI, A. Contributing to Global Management Knowledge: A Case for High Quality Indigenous Research. Asia Pacific Journal of Management, v. 21, n. 4, p. 491-513, 2004.
VAN KOLCK, O. L. Testes projetivos gráficos no diagnóstico psicológico. São Paulo: EPU Pedagógica e Universitária, 1984. 